\title{
The existence of High Conservation Value Forest (HCVF) in Perum Perhutani KPH Kendal to support Implementation of FSC Certification
}

\author{
Sri Sulistyowati ${ }^{1, *}$, Sudharto P. Hadi ${ }^{2}$ \\ ${ }^{1}$ Master Program of Environmental Science, School of Postgraduate Studies, Diponegoro University 50241, Semarang - Indonesia \\ ${ }^{2}$ Faculty of Social and Political Science, Diponegoro University 50241, Semarang - Indonesia
}

\begin{abstract}
High Conservation Value Forest (HCVF) is the identification of High Conservation Values that are important and need to be protected. Under FSC certification mechanism, HCVF becomes one of Principles and Criteria to attain certification. In this study, we identify the existence of HCVF in Perum Perhutani KPH Kendal to support implementation process of FSC certification. Qualitative method was conducted through observation and secondary data from Perum Perhutani KPH Kendal. Data analysis showed through ecolabel certification, Perum Perhutani KPH Kendal has been identified HCVF area covering 2,715.5 hectares consists of HCV 1 until 6. Secondary Natural Forest (HAS) Subah and Kaliwungu for Ulolanang and Pagerwunung Nature Reserve buffer zone include as HCV 1.1, conservation area of leopard (Panthera pardus melas) and Pangolin (Manis javanica).for HCV 1.2, conservation area of lutung (Trachypiyhecus auratus) as endemic species for CITES App I and Critically Endangered species include as HCV 1.3, Goa kiskendo for bats species habitat include as HCV 1.4, regions of interest species for Deer (Cervus timorensis) and Kepodang (Oriolus chinensis) as HCV 2.3, Germplasm Protection Region/ KPPN area with high biodivers ity include as HCV 3, river border area and water springs for HCV 4. While, utilization of firewood, grass for cattle fodder include as HCV 5 and 14 cultural sites include as HCV 6. From monitoring and evaluation of HCVF data, showed that in 2011-2015 the level of diversity for flora and fauna were increased.
\end{abstract}

\section{Background}

Indonesia's forests are the third largest tropical forest in the world after Brazil and Congo covering forest area of $1,860,359.67 \mathrm{~km} 2$ and second ranks for biodiversity after Brazil. Sustainable forest management in tropical countries using mandatory command and control approaches are seen as unsuccessful project by green consumers, proving that the environment of tropical forests is getting decrease, including forest in Indonesia. Forest degradation in Indonesia has occurred with a very large scale area. According to the analysis of Forest Watch Indonesia in 2011, rate of deforestation in Indonesia during these three periods decreased due to the depletion of Indonesia's forest area of 1.8 million ha / year within the period of 1985-1997, about 2.84 million ha / year in the period of 1997-2000 and approximately 1.51 million ha / year during 2000-2009 [1].

Perum Perhutani as a state owned company that manage forest products area in Java and Madura Island, take a responsibility to create a sustainable forest. Ecolabel certification is a forest management instrument with the aim to maintain the sustainability of forest resources and their functions. The implementation of ecolabel certification in Perum Perhutani KPH Kendal uses Forest Stewardship Council (FSC) scheme. This study aims to determine the existence of High Conservation Value Forest (HCVF) in Perum Perhutani $\mathrm{KPH}$ Kendal and management forms undertaken to maintain environmental protection. $\mathrm{HCVF}$ is an area that has one or more High Conservation Values (HCVs). $\mathrm{HCV}$ is something that has high conservation value at the local, regional or global level that includes ecological values, environmental, social and cultural values [2].

\section{Research method}

This research was conducted at Perum Perhutani KPH Kendal, Regional Division of Central Java. Overall research method used qualitative method. Data collection was obtained through field observation and literature review analysis using Perum Perhutani KPH Kendal documents. Data analysis was conducted using descriptive qualitative method.

\footnotetext{
Corresponding author: iik.pht@gmail.com
} 


\section{Result and discussion}

\subsection{HCVF (High Consenation Value Forest) Identification result}

HCVF was introduced by FSC in 1999 based on FSC principle number 9. The concept of HCVF is intended to identify the existence of high conservation values existing in an area (forest) and the establishment of it's management and monitoring plan to maintain and / or enhance the conservation value.

HCVF is an area that has one or more High Conservation Values (HCV). HCV is something that has high conservation value at the local, regional or global level that includes ecological values, environmental, social and cultural services. In the HCVF concept, high conservation values (HCV) classified into six HCV values. Forest areas could be classified to be of high conservation value if they possess one or more of the following characteristics [2]:

HCV1: Forest areas that has a globally, regionally and locally important concentrations of biodiversity values (e.g. endemic species, endangered species, refugia).

HCV2: Forest areas that has locally important in global, regional and local landscape area, within or with a management unit, in which most species populations, or all species naturally present in the region, in distribution patterns and natural abundance.

HCV3: Forest areas within or rare, threatened or endangered ecosystems.

HCV4: Forest areas that act as natural regulators in critical situations (e.g. watershed protection, erosion control).

HCV5: Forest areas that is importance to meet the basic needs of local communities (e.g. fulfillment of basic needs, health).

HCV6: Forest areas that are critical to the traditional cultural identity of local communities (important cultural, ecological, economic, religious areas identified with local communities).

According to the HCV identification in Kendal forest area of 2,715.5 Ha consist of HCV 1, HCV 2, HCV 3, HCV 4, HCV 5 and HCV 6.

\subsubsection{HCV 1}

HCV 1.1 In the form of Secondary Natural Forest (HAS) Subah (Bufferzone CA Ulolanang) of 362.9 ha and Kaliwungu HAS (bufferzone CA Pagerwunung) covering $254.4 \mathrm{Ha}$.

HCV 1.2 is leopard (Phantera pardus melas) and Pangolin (Manis javanica).

HCV 1.3 in the form of Germ Plasm Protected Area compartment $9 \mathrm{RPH}$ Besokor area of 70.6 ha which is the habitat of leopard (Panthera pardus melas) habitat and HAS Subah area of $362.9 \mathrm{Ha}$ as Lutung habitat (Trachypithecus Auratus)

HCV 1.4 in the form of Kiskendo Cave of $6.5 \mathrm{Ha}$ as the habitat of temporary animals (bats).

\subsubsection{HCV 2}

$\mathrm{HCV} 2$ identified in KPH Kendal known as HAS Kaliwungu area of 254.4 Ha, HAS Curam area of 405.2 $\mathrm{Ha}$ and compartment 9 RPH Besokor (KPPN) of 70.6 Ha. This area is habitat for interest species like Leopard, Kepodang and Deer.

\subsection{HCV 3}

HCV 3 is a high diversity area located in Kendal KPH, compartment 9 (KPPN) of $70.6 \mathrm{Ha}$, compartment 44 of $49.5 \mathrm{Ha}$, compartment 61 a of $57,2 \mathrm{Ha}$ and compartment $39 \mathrm{f}$ of $12 \mathrm{Ha}$ at BKPH Sojomerto.

\subsection{HCV 4}

HCV 4.1 in KPH Kendal identified as springs, located in 13 sites covering $6.1 \mathrm{Ha}$ and River border area of 1.443, $4 \mathrm{Ha}$. Another HCV 4.2 is identified as Steep Secondary Natural Forest area of 405.2 Ha scattered in the forest area of KPH Kendal.

Table 1. HCVF areas in Perum Perhutani KPH Kendal

\begin{tabular}{|c|c|c|c|}
\hline No & HCV Target & $\begin{array}{c}\text { HCV } \\
\text { Category }\end{array}$ & Information \\
\hline 1 & $\begin{array}{l}\text { HAS } \\
\text { (Secondary } \\
\text { Natural Forest) } \\
\text { Subah }\end{array}$ & $1.1 ; 1.3$ & $\begin{array}{l}\text { Bufferzone Cagar } \\
\text { Alam Ulolanang; } \\
\text { Lutung } \\
\text { (Trachypithecus } \\
\text { Auratus) Habitat }\end{array}$ \\
\hline 2 & $\begin{array}{l}\text { HAS } \\
\text { Kaliwungu }\end{array}$ & $1.1 ; 2.3$ & $\begin{array}{l}\text { Bufferzone Cagar } \\
\text { Alam Pagerwunung; } \\
\text { Deer Habitat }\end{array}$ \\
\hline 3 & $\begin{array}{l}\text { Compartment } \\
98(\mathrm{KPPN})\end{array}$ & $1.3 ; 2.3 ; 3$ & \begin{tabular}{lr}
\multicolumn{2}{l}{ Leopard (Panthera } \\
pardus & melas \\
habitat; & RTE \\
Ecosystem &
\end{tabular} \\
\hline 4 & Copartment 44a & $3 ; 4.2$ & $\begin{array}{l}\text { RTE Ecosystem; } \\
\text { steep area }\end{array}$ \\
\hline 5 & $\begin{array}{ll}\text { HAS } & \text { Curam } \\
\text { (Steep) } & \\
\end{array}$ & $2.3 ; 4.2$ & $\begin{array}{l}\text { Kepodang habitat; } \\
\text { erosion control area, }\end{array}$ \\
\hline 6 & $\begin{array}{l}\text { Compartment } \\
\text { 61a (Curug } \\
\text { sewu) }\end{array}$ & $1.3 ; 3 ; 4.2$ & $\begin{array}{l}\text { Lutung \& } \\
\text { Kepodang habitat; } \\
\text { RTE Ecosystem; } \\
\text { Steep area }\end{array}$ \\
\hline 7 & $\begin{array}{l}\text { Compartment } \\
39\end{array}$ & $2.3 ; 3 ; 4.2$ & $\begin{array}{l}\text { Kepodang habitat; } \\
\text { RTE Ecosystem; } \\
\text { Steep area }\end{array}$ \\
\hline 8 & $\begin{array}{l}\text { Compartment } \\
67 \mathrm{j} \text { (Kiskendo } \\
\text { cave) }\end{array}$ & $\begin{array}{l}1.4 ; 2.3 ; \\
4.2\end{array}$ & $\begin{array}{l}\text { Bats \& Kepodang } \\
\text { habitat, HAS Curam } \\
\text { (Steep) }\end{array}$ \\
\hline 9 & $\begin{array}{ll}\text { Spring } & (13 \\
\text { location) }\end{array}$ & $4.1 ; 5$ & $\begin{array}{ll}\text { Clean } & \text { water } \\
\text { resources } & \end{array}$ \\
\hline 10 & Riparian zone & 4.2 & Water reservoir \\
\hline 11 & $\begin{array}{l}\text { Agro forestry } \\
\text { location, } \\
\text { Livestock } \\
\text { forage, Tree } \\
\text { branch (rencek) }\end{array}$ & 5 & Food resources \\
\hline 12 & $\begin{array}{l}\text { Cultural sites } \\
\text { (14 location) }\end{array}$ & 6 & Tomb cultural sites \\
\hline
\end{tabular}

Source: Monitoring and Evaluation of HCVF Document in KPH Kendal 2015 


\subsubsection{HCV 5}

HCV 5 is related with the fulfillment of basic human needs. Some of these activities, contributed by Perum Perhutani KPH Kendal to fulfill the basic needs such as intercropping system, utilization of firewood by the community from the forest, the fulfillment of forage needs and the source of clean water from the spring.

\subsubsection{HCV 6}

Perum Perhutani KPH Kendal identified 14 cultural sites which used by the community for the fulfillment of religious and cultural needs. Cultural sites located in KPH Kendal such as cultural tombs. These cultural sites usually used by local communities and outside areas to perform rituals such as alms earth, religious tourism, certain rituals (ascetic).

Detail identification of HCVF areas can be seen in the Table 1 .

\subsection{Management of HCVF areas}

In order to maintain and enhance the existence and function of HCV Areas, Perum Perhutani KPH Kendal undertakes some management such as:

\section{- Maintenance of HCVF boundary.}

-Counseling/socialization of illegal activities on HCVF areas

Counseling of illegal activities on HCVF areas in $\mathrm{KPH}$ Kendal such as illegal cutting prohibition, illegal forest fire prohibiton, wildlife hunting prohibition and wild cultivation and HCVF areas management to the stakeholders and communities who lives near forest areas.

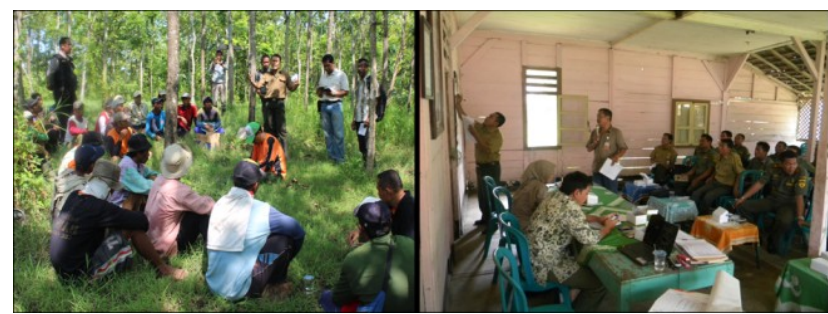

Fig. 1. Socialization activities on HCV areas

-Collaborative management (joint patrol) with BKSDA Central Java especially in HCVF area near Nature Reserve location.

-Prohibition and information boards establishment on HCVF protection at strategic HCVF locations.
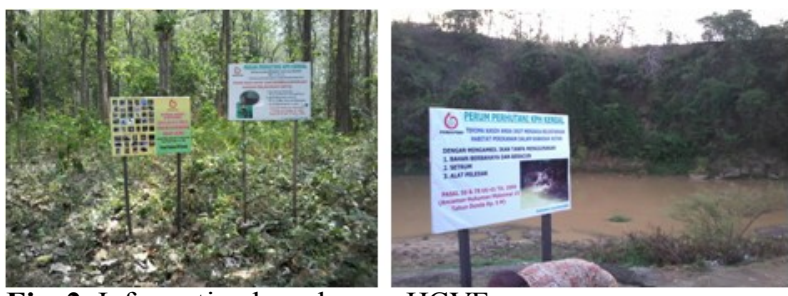

Fig. 2. Information boards near HCVF areas

\section{-Maintenance of cultural sites}

Perum Perhutani KPH Kendal has conducted maintenance in some cultural sites such as road improvement to site, information board establishment.

-Enrichment program conducted in protection areas in order to increase the diversity of vegetation by using local species. Enrichment is carried out in the area of Local Protection (KPS) and Secondary Natural Forest (HAS) which is in open area condition (open plek).

Table 2. Enrichment program in protected area

\begin{tabular}{|c|c|c|c|}
\hline No & Year & $\begin{array}{l}\text { Total } \\
\text { Area }\end{array}$ & Species \\
\hline 1. & 2011 & 124.9 ha & Rbc \\
\hline 2. & 2012 & 69.8 ha & $\begin{array}{l}\text { Kepuh, Trengguli, } \text { Salam, } \\
\text { Beringin, Johar, Duwet, Bendo, } \\
\text { Wungu }\end{array}$ \\
\hline 3. & 2013 & 360.8 ha & $\begin{array}{l}\text { Kepuh, Trengguli, Salam, } \\
\text { Beringin, Johar, Bambu, Duwet, } \\
\text { Bendo, Wungu }\end{array}$ \\
\hline 4. & 2014 & $105.8 \mathrm{ha}$ & $\begin{array}{l}\text { Kepuh, Trengguli, } \\
\text { Beringin, Johar, Bambu, Duwet, } \\
\text { Bendo, Wungu }\end{array}$ \\
\hline 5. & 2015 & 130.6 ha & $\begin{array}{l}\text { Kepuh, Trengguli, } \\
\text { Beringin, Johar, Bambu, Duwet, } \\
\text { Bendo, Wungu }\end{array}$ \\
\hline
\end{tabular}

Source: Annually planning Document in KPH Kendal 20112015

\subsection{HCV conditions}

3.3.1 Diversity of Flora in HAS Subah, HAS Kaliwungu and HAS Curam, Local Protection (KPS) (HCV $1.1 ; 1.3 ; 2.3 ; 4.2)$

Table 3. Divers ity of vegetation

\begin{tabular}{|c|c|c|c|c|c|c|}
\hline \multirow{2}{*}{ No } & \multirow{2}{*}{ Parameter } & \multicolumn{5}{|c|}{ HAS (Secondary Natural Forest) Subah } \\
\hline & & 2011 & 2012 & 2013 & 2014 & 2015 \\
\hline 1 & Aboveground vegetation & 1,945 & 1,920 & 2,031 & 2,366 & 2,121 \\
\hline 2 & Seedling & 1,358 & 1,589 & 1,593 & 2,221 & 2,598 \\
\hline 3 & Sapling & 0,941 & 0,958 & 0,982 & 1,433 & 2,700 \\
\hline 4 & Pole & 0,340 & 0,854 & 1,026 & 1,424 & 1,065 \\
\hline 5 & Tree & 0,216 & 0,941 & 0,998 & 1,195 & 1,337 \\
\hline
\end{tabular}




\begin{tabular}{|c|c|c|c|c|c|c|}
\hline \multirow{2}{*}{ No } & \multirow{2}{*}{ Parameter } & \multicolumn{5}{|c|}{ HAS (Secondary Natural Forest) Kaliwungu } \\
\hline & & 2011 & 2012 & 2013 & 2014 & 2015 \\
\hline 1 & Aboveground vegetation & 3,003 & 2,351 & 2,688 & 2,664 & 2,818 \\
\hline 2 & Seedling & 1,826 & 2,011 & 2,183 & 2,480 & 2,578 \\
\hline 3 & Sapling & 2,389 & 2,385 & 2,402 & 2,373 & 2,461 \\
\hline 4 & Pole & 0,000 & 0,566 & 0,637 & 1,303 & 1,695 \\
\hline 5 & Tree & 0,142 & 0,189 & 0,247 & 0,266 & 0,337 \\
\hline
\end{tabular}

\begin{tabular}{|c|c|c|c|c|c|c|}
\hline \multirow{2}{*}{ No } & \multirow{2}{*}{ Parameter } & \multicolumn{5}{|c|}{$\begin{array}{c}\text { steep }>\text { 40\% } \\
\text { (HAS Curam, Pt 9, Pt 61, pt 67j, pt.39f, pt 44) }\end{array}$} \\
\hline & & 2011 & 2012 & 2013 & 2014 & 2015 \\
\hline 1 & Aboveground vegetation & 2,206 & 2,596 & 2,662 & 2,288 & 2,288 \\
\hline 2 & Seedling & 3,584 & 3,215 & 3,429 & 3,446 & 3,492 \\
\hline 3 & Sapling & 3,213 & 3,244 & 3,245 & 3,129 & 3,052 \\
\hline 4 & Pole & 2,197 & 2,238 & 2,319 & 2,441 & 2,466 \\
\hline 5 & Tree & 2,396 & 2,432 & 2,436 & 2,467 & 2,472 \\
\hline
\end{tabular}

\begin{tabular}{|c|c|c|c|c|c|c|}
\hline \multirow{2}{*}{ No } & \multirow{2}{*}{ Parameter } & \multicolumn{5}{|c|}{ Riparian zone } \\
\hline & & 2011 & 2012 & 2013 & 2014 & 2015 \\
\hline 1 & Aboveground vegetation & 2,796 & 3,023 & 2,570 & 2,788 & 2,788 \\
\hline 2 & Seedling & 2,795 & 2,820 & 2,068 & 2,456 & 2,490 \\
\hline 3 & Sapling & 2,384 & 2,539 & 2,560 & 2,533 & 2,084 \\
\hline 4 & Pole & 2,341 & 2,447 & 1,647 & 2,374 & 2,383 \\
\hline 5 & Tree & 1,663 & 1,735 & 1,737 & 1,450 & 1,460 \\
\hline
\end{tabular}

Source : Monitoring and Evaluation of Biodiversity Document in KPH Kendal 2016

3.3.2 Biodiversity of fauna in HAS Subah, HAS Kaliwungu and HAS Curam, Local Protection (KPS) (HCV $1.1 ; 1.3 ; 1.4 ; 2.3 ; 4.2$ )

Table 4. Diversity of fauna

\begin{tabular}{|c|r|r|r|r|r|r|r|}
\hline \multirow{2}{*}{ No } & \multirow{2}{*}{ Tahun } & \multicolumn{3}{|c|}{ HAS Subah } & \multicolumn{3}{|c|}{ HAS Kaliwungu } \\
\cline { 3 - 8 } & & aves & mamalia & herpet & aves & mamalia & herpet \\
\hline 1 & 2011 & 2.300 & 0.000 & 0.598 & 3.150 & 1.369 & 1.630 \\
\hline 2 & 2012 & 2.490 & 0.000 & 1.471 & 3.118 & 2.480 & 1.427 \\
\hline 3 & 2013 & 2.604 & 0.000 & 1.101 & 3.122 & 2.533 & 1.810 \\
\hline 4 & 2014 & 2.920 & 0.474 & 1.600 & 3.507 & 1.593 & 1.992 \\
\hline 5 & 2015 & 2.675 & 1.265 & 1.838 & 3.002 & 1.110 & 2.041 \\
\hline
\end{tabular}

\begin{tabular}{|l|r|r|r|r|r|r|r|}
\hline \multirow{2}{*}{ No } & \multirow{2}{*}{ Tahun } & \multicolumn{3}{|c|}{$\begin{array}{c}\text { steep > 40\% } \\
\text { (HAS Curam, Pt 9, Pt 61, pt 67j, } \\
\text { pt.39f,pt 44) }\end{array}$} & \multicolumn{3}{|c|}{ riparian zone } \\
\cline { 3 - 8 } & & aves & mamalia & \multicolumn{1}{|c|}{ herpet } & aves & mamalia & herpet \\
\hline 1 & 2011 & 3,142 & 1,504 & 2,332 & 3,093 & 1,310 & 1,346 \\
\hline 2 & 2012 & 3,143 & 1,721 & 2,572 & 3,126 & 1,740 & 1,555 \\
\hline 3 & 2013 & 3,452 & 1,811 & 2,575 & 2,922 & 1,659 & 1,824 \\
\hline 4 & 2014 & 3,060 & 2,335 & 2,579 & 2,813 & 1,659 & 1,763 \\
\hline 5 & 2015 & 2,864 & 2,074 & 2,530 & 2,642 & 1,647 & 1,195 \\
\hline
\end{tabular}

Source : Monitoring and Evaluation of Biodiversity Document in KPH Kendal 2016

In areas which identified as HCV 1 to 4 above, HCV with good conditions are characterized by the increasing levels of different types of flora and fauna in some of these areas.

\subsubsection{Springs debit (HCV $4.1 ; 5)$}

Table 5. Springs debit data

\begin{tabular}{|c|l|r|r|r|r|r|}
\hline \multirow{2}{*}{ No } & \multirow{2}{*}{ Spring name } & \multicolumn{5}{|c|}{ debit (m3/second) } \\
\cline { 3 - 7 } & & 2011 & 2012 & 2013 & 2014 & 2015 \\
\hline 1 & Cokro tulung & 0,00025 & 0,00009 & 0,0001 & 0,0005 & 0,0003 \\
\hline 2 & Kali alang & 0,00046 & 0,0005 & 0,003 & 0,09 & 0,003 \\
\hline 3 & Kuthung muno & 0,00022 & 0,0002 & 0,004 & 0,02 & 0,01 \\
\hline 4 & Tuk cabe & 0,00002 & 0,00004 & 0,0004 & 0,0004 & 0,0001 \\
\hline 5 & Tuk kalibathang & 0,00012 & 0,08 & 0,07 & 0,006 & 0,0002 \\
\hline 6 & Tuk pancuran & 0,0016 & 0,003 & 0,008 & 0,0002 & 0,0001 \\
\hline 7 & Ngasinan & 0,004 & 0,005 & 0,0005 & 0,002 & 0,004 \\
\hline 8 & Petak (compartment) 27 a & 0,00058 & 0,004 & 0,003 & 0,009 & 0,0009 \\
\hline 9 & petak 56a & 0,00023 & 0,0003 & 0,001 & 0,0001 & 0,0003 \\
\hline 10 & Sekenyes & 0,00023 & 0,0002 & 0,001 & 0,004 & 0,0004 \\
\hline 11 & Tuk dandang & 0,00014 & 4,9 & 0,007 & 0,0005 & 0,004 \\
\hline 12 & Tuk tumpang & 0,0000033 & 0,00002 & 0,0006 & 0,001 & 0,002 \\
\hline 13 & Si rendeng & 0,000018 & 0,0001 & 0,005 & 0,004 & 0,02 \\
\hline
\end{tabular}

Source: Monitoring and Evaluation of HCVF Document in KPH Kendal 2015

\subsubsection{Tumpangsari (agroforestry), forage animal feed (HMT) and Rencek/ branches (HCV 5)}

From monitoring and evaluation result of HCVF KPH Kendal in 2015, showed that the community near forest can fulfill their life needs from intercropping, forage animal feed (HMT) and rencek. Annual data shows an increasing income, which can be seen in the following table:

Table 6. Data of Income from Tumpangsari (agroforestry)

\begin{tabular}{|c|c|c|c|c|c|c|}
\hline \multirow{4}{*}{ Year } & \multicolumn{6}{|c|}{ Comodity } \\
\hline & \multicolumn{2}{|c|}{ Rice } & \multicolumn{2}{|c|}{ Corn } & \multicolumn{2}{|c|}{ Others } \\
\hline & Total & Price & Total & Price & Total & Price \\
\hline & (TON) & (X1000) & (TON) & (X1000) & (TON) & (X1000) \\
\hline 2011 & 90,3 & 270.900 & 3.475 & 6.950 .256 & 152 & 5.390 .543 \\
\hline 2012 & 132 & 396.000 & 3.357 & 7.384 .647 & 569 & 3.368 .059 \\
\hline 2013 & 44 & 202.200 & 2.434 & 6.298 .138 & 169 & 7.384 .866 \\
\hline 2014 & 81 & 328.850 & 784 & 7.329 .509 & 584 & 785.255 \\
\hline 2015 & - & 304.500 & 2.926 & 8.341 .475 & 1.155 & 8.687 .820 \\
\hline 2016 & 53 & 157.500 & 2.788 & 8.687 .820 & 645 & 2.597 .091 \\
\hline
\end{tabular}

Source : Annual report of social management in 2011-2016

Table 7. Data of Income from branches

\begin{tabular}{|c|c|r|r|}
\hline No & Year & Volume (bundle) & \multicolumn{1}{c|}{ Total (IDR) } \\
\hline 1 & 2011 & 244.477 & 1.222 .385 \\
\hline 2 & 2012 & 279.922 & 1.804 .977 \\
\hline 3 & 2013 & 87.189 & 828.295 .500 \\
\hline 4 & 2014 & 84.237 & 768.170 .000 \\
\hline 5 & 2015 & 129.681 & 1.695 .075 .000 \\
\hline
\end{tabular}


Table 8. Data of Income from forage animal feed (HMT)

\begin{tabular}{|c|c|r|r|}
\hline \multirow{2}{*}{ No } & \multirow{2}{*}{ Year } & \multicolumn{2}{|c|}{ Forage animal feed } \\
\cline { 3 - 4 } & & $\begin{array}{c}\text { Volume } \\
\text { (bundle) }\end{array}$ & $\begin{array}{c}\text { Total } \\
\text { (IDR) }\end{array}$ \\
\hline 1 & 2011 & 44.671 & 53.604 .720 \\
\hline 2 & 2012 & 489.663 & 587.645 .000 \\
\hline 3 & 2013 & 60.528 & 565.659 .875 \\
\hline 4 & 2014 & 82.234 & 764.182 .500 \\
\hline 5 & 2015 & 72.848 & 828.311 .500 \\
\hline
\end{tabular}

Source : Annual report of social management in 2011-2016

\subsubsection{Cultural sites}

The cultural sites identified in the KPH Kendal are still exists and used by the community for several activities such as alms, hermits and traditions of local communities known as khoul activities at the Mbah Demang Sulang site compartment 105e, Ds. Kutosari Kec. Gringsing, Batang regency, the path to the onion bone site has been done. This shows that the cultural sites managed by KPH Kendal are still used by the community.

\section{Conclusions and suggestions}

\subsection{Conclusions}

1. HCVF areas were identified in Perum Perhutani KPH Kendal are HCV 1.1 for HAS Subah and HAS Kaliwungu as bufferzone of Ulolanang and Pagerwunung Nature Reserves, HCV 1.2 is leopard (Phantera pardus melas) and Pangolin (Manis javanica). HCV 1.3 for HAS Subah, pt 9 KPPN RPH Besokor, Pt 61a as lutung (Trachypithecus auratus) habitat and Pt 9 KPPN $\mathrm{RPH}$ Besokor as Macan tutul (Panthera pardus) habitat and $\mathrm{HCV} 1.4$ for Kiskendo cave as temporary habitat for some animals. HCV 2 for HAS Kaliwungu, HAS Curam (steep) Pt 9 RPH Besokor (KPPN) as spesies intereset habitat
(Macan Tutul, Kepodang and Rusa), HCV 3 for Pt 9 (KPPN), Pt 44, Pt 61a and Pt $39 \mathrm{f}$ with total area of $12 \mathrm{Ha}$ BKPH Sojomerto, HCV 4 for springs in 13 locations, Local protected area (KPS) and HAS Curam (steep) which spread in the forest area of $\mathrm{KPH}$ Kendal, $\mathrm{HCV} 5$ for tumpangsari (agroforestry), forage animal feed (HMT) and rencek/branches for firewood and HCV 6 for cultural sites which identified about 14 sites.

2. HCV area management activities conducted by Perum Perhutani KPH Kendal showed that the management could maintain and even improve the function and condition of HCVF area.

\subsection{SUGGESTIONS}

1. Maintaining and controlling the existence of HCVF area of Perum Perhutani KPH Kendal.

2. In order to protect HCVF areas, it is necessary needed to involve the participation from community around forest area.

\section{References}

1. Forest Watch Indonesia. Potret Keadaan Hutan Indonesia Periode Tahun 2000-2009 (2001)

2. Konsorsium Revisi HCV Toolkit Indonesia. Panduan Identifikasi Kawasan Bernilai Konservasi Tinggi di Indonesia. Tropenbos International Indonesia Programme. Balikpapan, (2008)

3. Perum Perhutani KPH Kendal. Laporan Monitoring dan Evaluasi Kawasan Bernilai Konservasi Tinggi (KBKT) tahun 2015 (2015)

4. Perum Perhutani KPH Kendal. Laporan Monitoring dan Evaluasi Biodiversity KPH Kendal Tahun 2016 (2016)

5. Perum Perhutani KPH Kendal. Laporan Kelola Sosial tahun 2011-2016 (2016) 